\title{
INOVASI PEMECAHAN PEMBELAJARAN BAHASA ARAB DI MADRASAH IBTIDAIYAH
}

\author{
Oleh: \\ Nurul Makrifah ${ }^{1}$ \\ Email: ryfa93@gmail.com
}

\begin{abstract}
This study is aimed to describe the challenge and the innovation of Arabic learning in Islamic Elementary school. The method of this research is descriptive qualitative thas is done by observation and liberary research. The result of this research showed that there are many obstacles of the Arabic learning in this global era that need several innovation to be implemented. The capability of Arabic knowledge should be implemented by a teacher of Arabic to grow the Arabic competence for students in Islamic Elementary School. Besides, several strategies and learning models should be appropriate with the psyche of students in Islamic Elementary School.
\end{abstract}

Keywords: innovation, arabic learning, islamic elementary school

\section{Pendahuluan}

Bahasa Arab merupakan bagian dari bahasa asing, namun bahasa ini sudah tidak asing lagi kita dengar, karena setiap muslim sudah mendengarnya sejak dia dilahirkan ke dunia, begitu seorang anak yang beragama Islam dilahirkan ke dunia maka orangtuanya akan mengazankannya atau mengiqomahkannya. Dari realitas ini, bahasa yang digunakan dalam azan maupun iqomah adalah bahasa Arab, bahasa yang sudah berumur ribuan tahun yang tetap digunakan lebih dari dua milliar pengguna, dan menyebar ke santero dunia. ${ }^{2} \mathrm{Hal}$ ini telah difirmankan oleh Allah surah Al-Hujuraat ayat 13 bahwasanya bahasa merupakan media atau sarana mengenal perbedaan yang ada dalam bangsa, suku, tradisi, budaya dan bahasa.

${ }^{1}$ Dosen Sekolah Tinggi Ilmu Tarbiyah “Al-Ibrohimy” Galis Bangkalan

2 Rahmaini, Strategi Pembelajaran Bahasa Arab Aktif dan Menarik (Medan, perdana publishing: 2015), 11. 


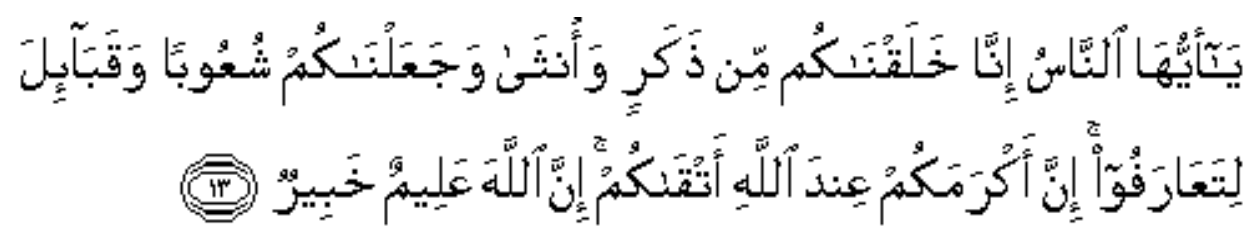

"Hai manusia, sesungguhnya Kami menciptakan kamu dari seorang lakilaki dan seorang perempuan dan menjadikan kamu berbangsa-bangsa dan bersuku-suku supaya kamu saling mengenal. Sesungguhnya orang yang paling mulia di antara kamu di sisi Allah ialah orang yang paling takwa di antara kamu. Sesungguhnya Allah Maha Mengetahui lagi Maha Mengenal."

Adapun bahasa Arab terdiri dari dua macam. Yang pertama adalah fusha dan yang kedua yaitu ammiyah. Arab fusha digunakan dalam situasi resmi, dan sering digunakan dalam penulisan formal. Arab fusha juga memiliki struktur atau tata bahasa dalam susunan kalimatnya yang memiliki unsur ilmu nahwu dan sharf. Arab fusha merupakan bahasa alQuran, sehingga orang-orang yang memiliki kemampuan bahasa Arab fusha adalah mereka yang benar-benar menekuni kaidah ilmu nahwu dan sharf sebagai dasarnya.

Bahasa Arab 'ammiyah digunakan dalam percakapan sehari-hari, dan biasanya digunakan dalam forum yang tidak resmi. 'Ammiyah tidak selalu berpacu pada tata bahasa atau struktur kalimat yang meliputi nahw dan sharf, karena bahasa ini adalah bahasa komunikasi yang mengikuti dialek masyarakat setempat. ${ }^{3}$

Belajar bahasa Arab diartikan belajar agama, karena Islam disampaikan menggunakan bahasa Arab. Sebagaimana firman Allah dalam al-Qur'an:

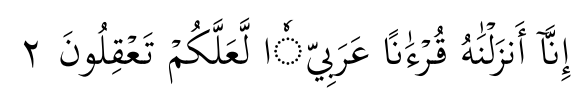

${ }^{3}$ Acep Hermawan, Metode Pembelajaran Bahasa Arab, (Bandung, PT. Remaja Rosdakarya: 2011), 91. 
Artinya: "Sesungguhnya Kami menurunkannya berupa al-Quran dengan berbahasa Arab, agar kamu memahaminya". ${ }^{4}$

Namun, dalam praktiknya, pembelajaran bahasa Arab menuai tantangan, sehingga membutuhkan inovasi dan pemecahan dalam pembelajaran bahasa Arab guna tercapainya tujuan pembelajaran secara efektif dan efisien. Inovasi-inovasi tersebut perlu diterapkan baik oleh pendidik maupun peserta didik, baik diselenggarakan oleh sekolah maupun lingkungan sekolah. Inovasi-inovasi tersebut bukan hanya terkait tentang praktik, namun juga tentang paradigma pentingnya pengembangan inovasi bahasa Arab dalam menghadapi tantangan zaman yang bersifat dinamis dan pengembangan ilmu yang semakin dinamis dan tidak stagnan.

\section{Pembahasan}

Dalam pembelajaran bahasa Arab terdapat empat keterampilan yaitu keterampilan mendengarkan, keterampilan berbicara, keterampilan membaca, dan keterampilan menulis. Namun, keterampilan yang paling mendasar dalam pembelajaran bahasa Arab adalah keterampilan mendengarkan dan keterampilan berbicara. Mendahulukan keterampilan mendengarkan dan beribicara buka lantas tidak mementingkan keterampilan membaca dan menulis, sebab keterampilan mendengarkan dan berbicara membutuhkan latihan khusus pada pendengaran dan latihan mengungkapkan. ${ }^{5}$

Namun alangkah lebih baik jika empat keterampilan dalam pembelajaran bahasa Arab dikuasai dengan baik oleh peserta didik. Di antaranya adalah $\mathrm{Al}$ Istima' (mendengarkan). Keterampilan mendengarkan merupakan kemampuan seseorang dalam memahami kalimat yang disampaikan oleh pembicara. Kemampuan mendengarkan dapat dicapai dengan latihan yang kontinu untuk mendengarkan perbedaan-perbedaan

\footnotetext{
${ }_{5}^{4}$ QS. Yusuf ayat 2

5 Taufik, Pembelajaran Bahasa Arab MI (Surabaya: UIN Sunan Ampel Press, 2016), 41-43.
} 
bunyi unsur-unsur kata. Al Kalam (berbicara), keterampilan berbicara adalah kemampuan mengungkapkan kata-kata untuk mengekspresikan pikiran, pendapat, keinginan atau perasaan kepada pihak lain. Keterampilan berbicara bertujuan supaya peserta didik mampu berkomunikasi lisan secara baik dengan bahasa yang telah mereka pelajari. ${ }^{6}$ Al Qira'ah (membaca), keterampilan membaca adalah kegiatan yang meliputi pola berpikir, menilai, menganalisis, dan memecahkan masalah. ${ }^{7}$ Pada hakikatnya membaca merupakan proses komunikasi antara pembaca dan penulis melalui teks yang ditulisnya, maka secara langsung di dalamnya ada hubungan kognitif antara bahasa lisan dan tulisan. ${ }^{8}$ Al Kitabah (menulis), menulis adalah salah satu keterampilan berbahasa yang ekspresif dan produktif. Dikatakan ekspresif karena menulis merupakan hasil pikiran dan perasaan yang dapat dituangkan melalui aktivitas dengan menggerakkan motorik halus melalui goresangoresan tangan, dan dikatakan produktif karena menulis menghasilkan karya nyata. ${ }^{9}$

\section{Tantangan Pembelajaran Bahasa Arab}

Tantangan pembelajaran bahasa Arab tidak bisa dilihat hanya dari sudut aspek yang sempit. Akan tetapi tantangan ini beragam dari berbagai aspek yang luas yang mempengaruhi proses pembelajaran bahasa Arab khususnya di tingkat Madrasah Ibtidaiyah (MI). Tantangan di sini dipengaruhi oleh tantangan zaman yang dari waktu ke waktu sangat dinamis dan berubah dari zaman ke zaman sehingga butuh adanya pemecahan dan inovasi mulai dari membentuk tenaga pendidik bahasa Arab yang profesional, hingga proses pembelajaran yang inovatif baik dari

\footnotetext{
${ }^{6}$ Ibid., 135-136

Abd Wahab Rosyidi dan Mamlu'atul Ni'mah Memahami Konsep Dasar Pembelajaran Bahasa Arab (Malang: UIN-Maliki Press, 2012), 95.

${ }^{8}$ Hermawan, Metodologi Pembelajaran Bahasa Arab, 143.

${ }^{9}$ Vera Sardila, "Strategi Pengembangan Linguistik Terapan Melalui kemampuan Menulis Biografi dan Autobiografi: Sebuah Upaya Membangun Keterampilan Menulis Kreatif Mahasiswa", Jurnal Pemikiran Islam, Vol. 40 No. 2 (Juli-Agustus, 2015), 113.
} 
segi pengembangan media, bahan ajar, dan lain sebagainya. Tantangantantangan tersebut meliputi di antaranya:

a. Bahasa Arab dalam arus globalisasi

Hidup di era digital sekaligus era globalisasi tentu saja diakibatkan oleh kemajuan yang pesat di bidang sains dan teknologi, terutama teknologi komunikasi dan informatika. Perkembangan dan perubahan dalam segala aspek kehidupan menjadi sangat cepat dan pesat. Sedangkan bahasa Arab sudah mulai dikenal oleh bangsa Indonesia sejak Islam dikenal dan dianut oleh mayoritas bangsa Indonesia. Jika Islam secara meluas telah dianut oleh masyarakat kita pada abad ke-13, maka usia pendidikan bahasa Arab dipastikan sudah lebih dari 7 abad. Karena perjumpaan umat Islam Indonesia dengan bahasa Arab itu paralel dengan perjumpaannya dengan Islam. Dengan demikian, bahasa Arab di Indonesia jauh lebih "tua dan senior" dibandingkan dengan bahasa asing lainnya. ${ }^{10}$

Namun demikian, jika dibandingkan dengan bahasa Inggris yang bercitra lebih baik, mengapa bahasa Arab tampaknya termarginalkan oleh arus globalisasi. Citra bahasa Arab tampaknya kurang menggembirakan. Apakah posisi bahasa Arab sebagai bahasa kitab suci al-Qur'an dan Sunnah Nabi Muhammad Saw selama ini tidak cukup memberikan daya dorong (inspirasi dan motivasi) bagi umat Islam untuk mau mengkajinya secara lebih intens? Apakah studi basaha Arab di Indonesia hanya dipacu oleh semangat (motivasi) untuk memahami ajaran Islam semata, dan terbatas di kalangan kaum tradisional "santri" saja? inilah tantangan bahasa Arab di zaman globalisasi.

b. Kemajuan media dan teknologi

Media pembelajaran merupakan sebuah salah satu rukun yang harus ada dalam dunia pembelajaran. Karena media memiliki peran penting dalam proses pembelajaran. Kata media berasal dari bahasa latin yaitu "medius" yang secara harfiah memiliki arti tengah, perantara, atau pengantar. Dalam bahasa Arab, media adalah sebuah perantara

${ }^{10}$ Ubaid Ridlo, "Bahasa Arab dalam Pusaran Arus Globalisasi: antara Pesismisme dan Optimisme”, Ihya' Arabiyah”, (Vol.2, Desember 2015), 210. 
(wasaail) atau pengantar pesan pengirim kepada penerima pesan.11 Secara lebih husus, media dalam proses pembelajaran diartikan sebagai alat-alat grafis, fotografis, atau elektronis untuk menangkap, memproses, dan menyusun kembali informasi visual atau verbal. ${ }^{12}$

Di tengah kemajuan media dan teknologi, banyak sekali aspek positif dan negatif. Hal ini menjadikan peserta didik terbiasa dengan hal-hal yang bersifat praktis dan instan. Padahal bahasa mampu diserap dengan beberapa tahapan dan proses. Hal demikian banyak menyebabkan turunnya minat dan motivasi belajar bahasa Arab yang rendah. ${ }^{13}$ Sehingga pendidik membutuhkan metode dan strategi pembelajaran yang menarik yang mendorong keaktifan siswa untuk mempelajari bahasa Arab. Berbagai media juga diharapkan mampu meningkatkan motivasi belajar siswa melalui sarana dan prasarana sekolah atau kreatifitas guru itu sendiri.

Secara umum, sarana dan prasarana pembelajaran bahasa Arab masih terlihat sangat sederhana dan terbilang monoton. Hal ini mengambil sedikit bagian dari beberapa kondisi yang mempengaruhi proses dan kualitas belajar para pembelajar. Sedangkan media ajar yang digunakan pun sifatnya sangat sederhana, seperti alat peraga berupa miniatur beberapa benda, gambar-gambar, dan melibatkan benda-benda yang ada di sekitar ruang belajar. Hal yang monoton seperti demikian tentu akan membuat mood belajar menurun karena suasana belajar flat, dan kurang interaktif. ${ }^{14}$

c. Metode dan strategi pembelajaran bahasa Arab

Pembelajaran bahasa Arab dewasa ini yang menggunakan metodemetode lama yang masih mengandalkan metode ceramah, sehingga pembelajaran yang kreatif dan menyenangkan tidak tampak dan

${ }^{11}$ Azhar Arsyad, Media Pembelajaran, (Jakarta: PT Raja Grafindo Persada, 2013), hal 3

12 Acep Hermawan, Metodologi Pembelajaran Bahasa Arab, (Bandung: PT Remaja Rosdakarya, 2011), hal 223

${ }^{13}$ Acep Hermawan, Metode Pembelajaran Bahasa Arab, (Bandung, PT. Remaja Rosdakarya: 2011), 95.

${ }^{14}$ Iin Suryaningsih, "Inovasi Media Ajar Bahasa Arab Bagi Orang Tua Didik", Jurnal al-azhar indonesia seri humaniora, (Vol. 4, No. 3, Maret 2018), 147. 
kelihatan, baik di jenjang universitas, pesantren-pesantren, madrasahmadrasah dan sekolah Islam terpadu khususnya Madrasah Ibtidaiyah. Berdasrkan pengamatan penulis ternyata masih banyak pengajar bahasa Arab yang belum menerapkan strategi pembelajaran yang kereatif dan menyenangkan sehingga imbasnya proses pembelajaran bahasa Arab belum mampu mencapai target atau hasil yang maksimal sesuai yang diharapkan, disisi lain para anak didik merasa jenuh dan bosan. ${ }^{15}$

\section{Inovasi Pembelajaran Bahasa Arab di Madrasah Ibtidaiyah}

\section{a. Inovasi dalam menghadapi tantanmgan zaman}

Menghadapi zaman yang dinamis di tengah arus globalisasi, seorang pendidik bahasa Arab di Madrasah Ibtidaiyah harus memiliki bekal untuk menangkis pergolakan zaman. Salah satunya dengan bekal pemahaman dan keilmuan bahasa Arab itu sendiri yang antara lain adalah:

1) Mengenal potensi bahasa Arab

Bahasa Arab merupakan bahasa yang paling banyak menyandang atribut. Selain merupakan bahasa kitab suci al-Qur'an dan Hadits Nabi Muhammad Saw, bahasa Arab adalah bahasa agama umat Islam, bahasa resmi Perserikatan Bangsa-Bangsa (PBB), bahasa nasional lebih dari 22 negara di kawasan Timur Tengah, dan bahasa warisan sosial budaya.

2) Memiliki orientasi pendidikan bahasa Arab

a) Orientasi religius, yaitu belajar bahasa Arab untuk tujuan memahami dan memahamkan ajaran Islam (fahm al-maqrû'). Orientasi ini dapat berupa belajar keterampilan pasif (mendengar dan membaca), dan dapat pula mempelajari keterampilan aktif (berbicara dan menulis)

b) Orientasi akademik, yaitu belajar bahasa Arab untuk tujuan memahami ilmu-ilmu dan keterampilan berbahasa Arab (istimâ', kalâm, qirấah, dan kitâbah). ${ }^{16}$

15 Rahmaini, Strategi Pembelajaran Bahasa Arab Aktif dan Menarik (Medan, perdana publishing: 2015), 5

${ }^{16}$ Ubaid Ridlo, "Bahasa Arab dalam Pusaran Arus Globalisasi: antara Pesismisme dan Optimisme”, Ihya' Arabiyah”, (Vol.2, Desember 2015), 211-218. 
3) Memahami prospek pendidikan bahasa Arab

Setiap tantangan pasti memberi peluang dan prospek jika kita berusaha menghadapi tantangan itu dengan positif. antara lain:

a) Peluang untuk mengembangkan bahasa Arab semakin terbuka. karena orang yang memiliki modal besar pengetahuan bahasa Arab akan berpotensi besar untuk mengembangkan kelimuan bahasa Arab maupun keilmuan tentang Islam.

b) Pengembangan profesi keguruan menjadi tenaga pengajar bahasa Arab yang professional.

c) Penggiatan dan pembudayaan tradisi penelitian dan pengembangan metodologi pembelajaran bahasa Arab.

d) Intensifikasi penerjemahan karya-karya berbahasa Arab baik tentang keilmuan bahasa atau keislaman.

e) Intensifikasi akses dan kerjasama dengan pihak luar negeri.

f) Pengembangan media dan teknologi.

g) Tenaga pendidik sebaiknya memiliki karya-karya akademik ${ }^{17}$

\section{b. Inovasi Alat Pembelajaran Bahasa Arab}

Pemicu ketidakberhasilan belajar bahasa Arab salah satunya adalah media yang digunakan pendidik kurang sesuai dengan jiwa dan karakter peserta didik. Dalam proses belajar mengajar penggunaan media yang tepat sangat berpengaruh terhadap terciptanya suasana pembelajaran yang menyenangkan, sehingga peserta didik senang dan giat untuk belajar. Apalagi didukung oleh adanya media pembelajaran yang menarik dan sesuai dengan materi. Karena media merupakan alat untuk pembelajaran yang menunjang keefektifan pembelajaran, seharusnya media juga didukung oleh meningkatnya sarana dan prasarana sekolah. Berikut adalah media-media yang cocok diterapkan di sekolah-sekolah yang fasilitasnya memadai.

${ }^{17}$ Acep Hermawan, Metode Pembelajaran Bahasa Arab, (Bandung, PT. Remaja Rosdakarya: 2011), 96-98 
1) LCD dan speaker aktif: media/perangkat ajar untuk menunjang keberhasilan pembelajar bahasa sebagai alat pendukung penguasaan kemahiran mendengar disamping melatih kecermatan peserta didik dalam menganalisis alur cerita yang di tayangkan.

2) CD dan VCD: media/perangkat ajar yang akan memberikan tema-tema yang sangat variatif, yang disesuaikan dengan tujuan pembelajaran.

3) Kertas/karton warna: media/perangkat ajar pendukung yang digunakan untuk bermain acak kata/kalimat berbahasa Arab agar peserta merasa lebih mudah menghafalkan kosa kata tertentu secara bersama-sama

4) Ruang multimedia: perangkat ini sebenarnya sangat penting untuk menunjang pembelajaran bahasa Arab. Dengan fasilitas ini, pembelajar akan merasakan nuansa berbeda dan dapat mengeksplorasi bahan ajar yang variatif melalui multimedia berbasis internet ini. ${ }^{18}$

\section{c. Inovasi media pembelajaran, yaitu :}

1) Media audio (al-wasa'il al-sam'iyyah), segala sesuatu yang bisa dimanfaatkan untuk memudahkan siswa dalam mempelajari materi dalam pembelajaran bahasa ataupun yang lainnya yang dapat ditangkap melalui indra pendengaran disebut dengan media audio. Lebih singkatnya media yang hanya dapat didengar saja atau media yang hanya memiliki unsur suara. ${ }^{19}$ Misalnya saja bahasa, radio, tape recorder, radio transistor, laboratorium bahasa, dan sebagainya,

2) Media visual (al-wasa'il al-bashariyyah), segala sesuatu yang bisa dimanfaatkan untuk memudahkan siswa dalam mempelajari materi dalam pembelajaran bahasa ataupun yang lainnya yang dapat ditangkap melalui indra penglihatan disebut dengan media visual. Lebih singkatnya media visual adalah media yang hanya dapat dilihat

${ }^{18}$ In Suryaningsih, "Inovasi Media Ajar Bahasa Arab Bagi Orang Tua Didik", Jurnal al-azhar indonesia seri humaniora, (Vol. 4, No. 3, Maret 2018), 148.

${ }^{19}$ Wina Sanjaya, Media Komunikasi Pembelajaran, (Jakarta : PrenadaMedia Group, 2016), hal 118 
saja yang tidak mengandung unsur suara. ${ }^{20}$ Misalnya benda asli, benda tiruan, gambar, segala barang yang ada di lingkungan sekolah seperti: papan tulis, meja, kursi, flash card, short card, buku teks, buletin, koran, dan lain sebagainya.

3) Media audio-visual (al-wasa'il al sam'iyyah al-bashariyyah), segala sesuatu yang bisa dimanfaatkan untuk memudahkan siswa dalam mempelajari materi pembelajaran bahasa ataupun yang lainnya yang dapat ditangkap melalui indra pendengaran dan indra penglihatan disebut dengan media audio-visual. ${ }^{21}$ Lebih singkatnya media audio-visual adalah media yang mengandung unsur suara dan juga media tersebut dapat dilihat.22 Misalnya saja televisi, video, CD, film, laboratorium bahasa multimedia, LCD Projektor, internet, dan sebagainya.

\section{d. Inovasi Metode Pembelajaran Bahasa Arab}

Menurut Ibnu Khaldun sesungguhnya pembelajaran itu merupakan profesi yang membutuhkan pengetahuan, keterampilan, dan kecermatan karena ia sama halnya dengan pelatihan kecakapan yang memerlukan kiat, strategi dan ketelatenan, sehingga menjadi cakap dan profesional. Penerapan metode pembelajaran tidak akan berjalan dengan efektif dan efisien sebagai media pengantar materi pembelajaran, apabila penerapannya tidak didasari dengan pengetahuan yang memadai tentang metode itu sendiri. Dengan kata lain bahwa metode itu bisa saja akan menjadi penghambat jalannya proses pembelajaran dan bukan menjadi bagian dari perangkat yang menunjang pencapaian tujuan jika tidak tepat aplikasinya.

1) Metode pembelajaran bahasa Arab tradisional

Metode tradisional merupakan metode pembelajaran bahasa Arab yang terfokus pada "bahasa sebagai budaya ilmu" sehingga belajar

${ }^{20}$ Wina Sanjaya, Media Komunikasi Pembelajaran, (Jakarta : PrenadaMedia Group, 2016), hal 118

21 Acep Hermawan, Metodologi Pembelajaran Bahasa Arab, (Bandung: PT Remaja Rosdakarya, 2011), hal 227

${ }^{22}$ Wina Sanjaya, Media Komunikasi Pembelajaran, (Jakarta: Prenada Media Group, 2016), hal 118 
bahasa Arab berarti belajar secara mendalam tentang seluk-beluk ilmu bahasa Arab, baik aspek gramatika/sintaksis (qawaid al-nahwu), morfem/morfologi (qawaid al-sharf) ataupun sastra (adab). ${ }^{23}$ Metode ini belum relevan diaplikasikan pada siswa Madrasah Ibtidaiyah karena meninjau aspek psikologi dan perkembangan kognitifnya. Penerapan qawaid disampaikan secara natural melalui ungkapan sederhana tanpa menjelaskan dengan detail usur nahw sharf itu sendiri.

Contoh yang terkenal akhir-akhir ini adalah pembelajaran bahasa Arab metode al-miftah yang diciptakan oleh tim dari Pondok Pesantren Sidogiri. Penerapan metode ini banyak diterapkan di sekolah-sekolah Islam dengan penambahan alokasi waktu selain pada jam pelajaran. Metode ini masih terbilang klasik yaitu dengan teacher centered yakni guru menjelaskan qawaid bahasa Arab dan disusul dengan hafalanhafalan siswa tentang qawaid yang dibentuk dengan nada syair atau nadham. Guru juga aktif melempar pertanyaan-pertanyaan pada siswa terkaid qawaid nahw dan sharf, sehingga siswa mampu menganalisis qawaid dengan sendirinya. Program sudah banyak mencetak siswasiswa mahir membaca kitab kuning dengan waktu yang terbilang cepat.

2) Metode Pembelajaran bahasa Arab modern

Pembelajaran yang berorientasi pada tujuan bahasa sebagai alat. Artinya, bahasa Arab dipandang sebagai alat komunikasi dalam kehidupan modern, sehingga inti belajar bahasa Arab adalah kemampuan untuk menggunakan bahasa tersebut secara aktif dan mampu memahami ucapan/ungkapan dalam bahasa Arab. Metode yang lazim digunakan dalam Pembelajarannya adalah metode langsung (tariiqah al-mubasysyarah).

Munculnya metode ini didasari pada asumsi bahwa bahasa adalah sesuatu yang hidup, oleh karena itu harus dikomunikasikan dan dilatih terus sebagaimana anak kecil belajar bahasa. Dalam perkembangannya, metode pembelajaran bahasa Arab yang juga merupakan bahasa Asing yang banyak diminati khususnya oleh negara-negara berpenduduk mayoritas muslim seperti Indonesia semakin berkembang sesuai

${ }^{23}$ Taufik, Pembelajaran Bahasa Arab MI, (Surabaya, UINSA Press: 2016), 4.

Volume 11 Nomor 1 Maret 2020

Approved: 17-01-2020, Accepted: 20-01-2020, Submitted: 11-02-2020 
dengan perkembangan metode pembelajaran bahasa-bahasa Asing lainnya seperti bahas Inggris karena dianggapnya seperti bahasa Asing pertama yang banyak ditekuni dan dipelajari serta dikembangkan pembelajarannya baik dari sisi metode, materi bahkan tumbuhkembangnya lembaga-lembaga pembelajaran bahasa Inggris. ${ }^{24}$

Demikian itu menunjukkan bahwa bangsa ini sangat membutuhkan bahasa Asing sepertu bahasa Arab, sehingga pengenalan tentang metode-metode pembelajaran bahasa Arab yang diadopsi dari metode-metode pembelajaran bahasa Asing lainnya seperti bahasa Inggris baik metode pembelajaran tradisional maupun modern perrlu disampaikan kepada para pembelajar dan dikembangakan agar menghasilkan out-put pembelajar bahasa yang memiliki efisiensi dan efektifitas yang tinggi, sehingga dengan waktu yang relatif singkat mereka dapat menguasai bahasa Arab baik kemampuan menyimak dan berbicara (al-Istima' wa al-Kalam), membaca (al-Qiroa'ah) maupun menulis (al-Kitabah) sesuai dengan keterampilan keterampilan berbahasa yang harus dicapai dalam pembelajaran bahasa.

Saat ini di media sosial semarak dengan vlogger. Akan tetapi masih sedikit akun vlogger yang benar-benar mengaplikasikan sebuah ilmu terutama ilmu bahasa. Maka, seorang pendidik bisa mengembangkan keahlian teknologinya dengan membuat program aplikasi belajar seperti "ruang guru", atau bahkan mengajarkan bahasa Arab melalui vlog. Hal ini mampu menginspirasi atau memotivasi minat siswa tentang bahasa Arab itu sendiri.

\section{e. Inovasi Strategi Pembelajaran Bahasa Arab Aktif dan Menarik}

Strategi merupakan hasil kreasi serta inovasi para pengajar. Para tenaga pengajar berhak dan dituntut berkreasi dan berinovasi sesuai situasi dan kondisi di lapangan. ${ }^{25}$ Menurut Jean Piaget, perkembangan kognitif anak berusia antara 6 - 12 tahun berada pada tahap concrete-operational,

${ }^{24}$ Taufik, Pembelajaran Bahasa Arab MI, (Surabaya, UINSA Press: 2016), 4-5.

${ }^{25}$ Rahmaini, Strategi Pembelajaran Bahasa Arab Aktif dan Menarik, (Medan, perdana publishing: 2015), 6 . 
bahkan usia 6-7 tahun anak masih berada pada tahap pre-operational. Setelah berusia 11 tahun, barulah anak masuk pada tahap formaloperational. 26 Berikut adalah strategi yang relevan mengikuti perkembangan kognif peserta didik:

1) Strategi bermain, strategi ini memiliki kriteria sebagai berikut:

a) motivasi intrinsik (belajar sambil bermain)

b) bermain dengan menyenangkan

c) bermain dengan edukatif

d) bermain melihat aspek tujuannya

e) kelenturan dalam perilaku maupun situasi.

2) Strategi bercakap-cakap memiliki manfaat sebagai berikut:

a) alat pemuas kebutuhan anak

b) mengendalikan tingkah laku siswa

c) memiliki hubungan antar pribadi

d) dapat menyatakan peranan dan sikap

e) berfungsi heuristic (bersifat bertanya-tanya, seperti "mengapa demikian?")

f) memiliki fungsi imajinatif

g) fungsi informatif

3) Strategi demonstratif adalah strategi dengan menirukan apa yang diucapkan gurunya setelah ditunjukan benda yang harus dihapalkan. strategi memiliki manfaat sebagai berikut:

a) mampu memberikan ilustrasi dalam menjelaskan informasi pada peserta didik

b) dapat membantu meningkatkan daya pikir anak

4) Strategi projek (learning by doing) strategi John Dewey yaitu perolehan hasil belajar dengan mengerjakan tindakan-tindakan sesuai tujuannya.

a) Strategi bercerita (cerita lisan)

b) Menceritakan dongeng sambil menyelipkan kosa kata ${ }^{27}$

26 Imam Nur Hakim, "Pembelajaran Tematik-Integratif di SD/MI dalam Kurikulum 2013” Insania, (Vol. 19, No. 1, Januari - Juni 2014), 47

${ }^{27}$ Taufik, Pembelajaran Bahasa Arab MI, (Surabaya, PMN: 2011), 80-86.

Volume 11 Nomor 1 Maret 2020 


\section{Simpulan}

Tantangan yang dihadapi saat ini adalah hidup di era digital sekaligus era globalisasi yang diakibatkan oleh kemajuan yang pesat di bidang sains dan teknologi, terutama teknologi komunikasi dan informatika. Sehingga pendidik profesional harus mengenal potensi bahasa Arab yang merupakan bahasa yang paling banyak menyandang atribut. Selain merupakan bahasa kitab suci al-Qur'an namun juga bahasa Hadits Nabi Muhammad Saw. Pendidik juga harus memiliki orientasi pendidikan bahasa Arab baik orintasi religius maupun orientasi akademik, dan memahami prospek pendidikan bahasa Arab karena peluang untuk mengembangkan bahasa Arab semakin terbuka.

Prospek pendidikan bahasa Arab dilakukan dengan pengembangan profesi keguruan menjadi tenaga pengajar bahasa Arab yang profesional, penggiatan dan pembudayaan tradisi penelitian dan pengembangan metodologi pembelajaran bahasa Arab, intensifikasi penerjemahan karyakarya berbahasa Arab baik tentang keilmuan bahasa atau keislaman, intensifikasi akses dan kerjasama dengan pihak luar negeri, pengembangan media dan teknologi, serta memiliki karya-karya akademik.

Tantangan berikutnya adalah media dan teknologi di zaman modern. Media merupakan alat untuk pembelajaran yang menunjang keefektifan pembelajaran. LCD dan Speaker aktif bisa menjadi media/perangkat ajar untuk menunjang keberhasilan pembelajar bahasa sebagai alat pendukung penguasaan kemahiran mendengar. CD dan VCD, atau yang sederhana kertas/karton warna, atau bahkan ruang multimedia bisa dijadikan media pembelajaran yang efektif. Metode pembelajaran bahasa Arab juga diperlukan kekreatifan pendidik baik metode klasik maupun modern. metode modern bisa dilaksanakan dengan strategi pembelajaran bahasa Arab yang aktif dan menarik antara lain, strategi bermain, strategi bercakap-cakap, strategi demonstratif, strategi projek, strategi bercerita, dan menceritakan dongeng sambil menyelipkan kosa kata.

\section{DAFTAR PUSTAKA}


Arsyad, Azhar. 2013. Media Pembelajaran. Jakarta: PT Raja Grafindo Persada.

Hermawan, Acep. 2011. Metode Pembelajaran Bahasa Arab. Bandung: Remaja Rosdakarya.

Hakim, Imam Nur. 2014. Pembelajaran Tematik-Integratif di SD/MI dalam Kurikulum 2013. Insania. (Vol. 19, No. 1, Januari - Juni 2014),

Rahmaini. 2015. Strategi Pembelajaran Bahasa Arab Aktif dan Menarik. Medan: Perdana Publishing.

Ridlo, Ubaid. 2015. Bahasa Arab dalam Pusaran Arus Globalisasi: antara Pesismisme dan Optimisme. Ihya' Arabiyah. Vol.2, Desember 2015.

Rosyidi, Abd Wahab dan Mamlu'atul Ni'mah. 2012. Memahami Konsep Dasar Pembelajaran Bahasa Arab. Malang: UIN-Maliki Press.

Sanjaya, Wina. 2016. Media Komunikasi Pembelajaran. Jakarta: Prenada Media Group.

Sardila, Vera. 2015. Strategi Pengembangan Linguistik Terapan Melalui kemampuan Menulis Biografi dan Autobiografi: Sebuah Upaya Membangun Keterampilan Menulis Kreatif Mahasiswa. Jurnal Pemikiran Islam, Vol. 40 No. 2 (Juli-Agustus, 2015).

Suryaningsih, Iin. 2018. Inovasi Media Ajar Bahasa Arab Bagi Orang Tua Didik. Jurnal Al-Azhar Indonesia Seri Humaniora, Vol. 4, No. 3, Maret 2018.

Taufik. 2011. Pembelajaran Bahasa Arab MI. Surabaya: PMN.

Taufik. 2016. Pembelajaran Bahasa Arab MI. Surabaya: UINSA Press. 